\title{
多属性効用関数を用いた住民の都市環境評価モデルの開発 ${ }^{\dagger}$
}

\author{
前 田博* ・村上 周、太* \\ Development of Population's Urban Environment Evaluation Model \\ with Multiattribute Utility Function \\ Hiroshi Maeda* and Shuta Murakami*
}

Urban planning should be evaluated not only from the side of administration, but also from the side of population in order to reflect population's opinions and their interests. It is surely necessary to include population's urban evaluation model in the urban decision-making process, which quantitatively represents population's value of urban life environment, and by introducing this model it would be easily accomplished to help deciding a plan which is sufficiently incorporated population's dissatisfaction with urban environment and their conflict between various interested groups and several subregions. In this paper, we propose the population's urban evaluation model and describe a method to construct the model and the practical application to Tobata ward in Kitakyushu city. The model is constructed by introducing an additive multiattribute utility function.

The method mainly consists of the following procedures.

1) Constructing a goal hierarchy of urban environment.

2) Gathering population's questionairs which contain relative weights among goals and an unidimensional utility function in each goal.

3) Classifying population into sevaral common interested groups based on their weights and utility functions. In this stage, principal component analysis is usefuly applied.

4) Specifying a group utility function in each group.

5) Specifying the population's utility function by aggregating group utility functions. In

†第 6 回システムシンポジウムで発表（昭 $55 \cdot 7$ )

* 九州工業大学工学部 北九州市戸畑区仙水町 1-1

* Faculty of Engineering, Kyushu Institution of Technology, Kitakyushu

(Received November 19, 1981)

(Revised April 8, 1982) this stage, we propose three criterions on which indivdual utility functions are aggregated. One is equality criterion, another is goal utility satisfying criterion, and the other is goal consequence satisfying criterion.

As the result of application to Tobata ward, we obtained the population's urban evaluation model very well expressed problems which are currently confronted in Tobata and that, very effective informations about their welfare are obtained by their urban evaluations.

Keyword: multiattribute utility function, social welfare function, group decision, urban planning, urban environment evaluation model

\section{1.はじめに}

行政の意思決定過程に，住民意識をいかに反映させ るかという問題は，開かれた行政という観点から，近 年ますます重要視されている一方，自治体で現実に行 われている方法論は, 従来からの多岐選択方式のアン ケート調査が主流であり，その多くが，住民の要望， 現状評価の定性的な分析に留まっているといってもよ いであろう. 行政の使命である, 住民の厚生の増大と その公平な配分を，公正に，效率よく進めていくため には，住民が都市環境に対してもっている多様な価值 意識を，定量的に把握することが不可欠であろうし， その結果を行政の意思決定に反映させててそ，真の住 民意識の反映につながると確信する.

このような，住民の価值意識の定量化問題は，いま だ一意的な方法論は確立されていないがその重要性は 認識されつつあり, 幾つかの試み(1,2)がなされている.

以上の観点から本研究は，住民の価值意識を定量的 に表現しうる住民の都市環境評価モデルを，加法的多 属性効用関数を用いて開発することを目的とする.

この分野における従来の研究では, Bauer ${ }^{3), 4)}$, 小澤 ${ }^{2)}$ がある. Bauer は，所得階層によって分けられた集団 
の多属性効用関数が，仮設的に与えられ，それを住民 からいかに導出するかについてはなんら言及していな い. 小澤は，広島市を事例として，住民意識調査を基 にしているものの，属性間の合成が行政担当者によっ てなされる形式を取っており，純粋に住民の意識が反 映されていない，また，都市住民全体が単一の評価モ デルで表わされ，住民の価值意識の多様性の表現には 不十分であると思われる.

本論文では，住民の都市環境に対する選好構造調査 から，加法的多属性効用関数を用いた住民の都市環境 評価モデルの構築過程を述べる. ことで構築される評 価モデルでは, 類似の価值観をあつ人々を一つの利益 集団と見なして，住民がどのような特質をあつ利益集 団に分類されるのか，それらの利益集団の大きさはよ゙ れくらいか, 利益集団間の満足度格差はどれくらい か，地域間での満足度格差はどれくらいかといった多 様な情報を提供できるのが大きな特徽となっている.

最後に，本評価モデルを使って，都市環境の評価例 を示し，モデルの有効性を検討する．なお，本研究は 北九州市戸畑区を対象として実施されている.

\section{2. 住民の都市環境評価モデルへの準備}

この章では，住民の都市環境評価モデルを構築する ための準備として，モデル化に当っての理論的前提お よび，住民の都市環境選好構造調査について述べる.

\section{1 モデル化の理論的前提}

多属性効用理論は, 意思決定者が対象としている複 数の属性について，ある仮定を満たすならば，意思決 定者の多属性効用関数が，各属性の 1 次元効用関数の 関数で表わされるととを述べたものである5

本論文では，1人の住民の都市環境に対する選好構 造が加法的多属性効用関数

$$
\begin{aligned}
& U(\boldsymbol{x})=\sum_{i=1}^{n} \alpha_{i} \cdot u_{i}\left(x_{i}\right), \sum_{i=1}^{n} \alpha_{i}=1, \\
& 0 \leq u_{i}\left(x_{i}\right) \leq 100
\end{aligned}
$$

で表わされるととを仮定する，ととで， $\boldsymbol{x}=\left(x_{1}, x_{2} \cdots\right.$ $\left.x_{n}\right)$ は $n$ 個の属性の結果を表わすべクトル， $\alpha_{i}$ は属性 $i$ の重み, $u_{i}\left(x_{i}\right)$ は属性 $i$ の 1 次元効用関数である.

個人の選好構造の違いは， $\alpha_{i}$ の大きさの違い， $u_{i}$ $\left(x_{i}\right)$ の形の違いとして表わされる. そこで, 類似の $\alpha_{i}, u_{i}\left(x_{i}\right)$ を有する人々を集めると，一つの共通利益 集団 (以後, 集団之略す) が形成されると考え, その 集団の選好構造 $U_{k}(\boldsymbol{x})$ は, 集団に属する人々の平均 的な $\bar{\alpha}_{i k}, \bar{u}_{i k}\left(x_{i}\right)$ (後に定義する) を用いて

$$
U_{k}(\boldsymbol{x})=\sum_{i=1}^{n} \bar{\alpha}_{i k} \cdot \bar{u}_{i k}\left(x_{i}\right), \sum_{i=1}^{n} \bar{\alpha}_{i k}=1
$$

で表わされるとする.

ところで，個人の選好を合成して一意的な社会的效 用関数が決定されるかという問題に関して，アロウの 一般不可能性定理による否定見解が存在する. しかし ながら本論では，個人の選好が絶対的不動であるとす るよりはむしろ，民主的社会生活が営まれていく過程 で，社会内での協調，合意が十分可能であり，個人間 の選好の超個人的比較を許容するととによって，一意 的な社会的効用関数が決定されうるとする立場 ${ }^{6}$ に立 ว.

さて，都市をp地域に分割し，その中の地域 $j$ に居 住する人々が $r$ 個の集団に分類できたとし，地域 $j$ を 代表する地域効用関数 $U^{j}\left(x^{j}\right)$ の決定問題を考える.

地域 $j$ の地域効用関数を

$$
\begin{aligned}
& U^{j}\left(\boldsymbol{x}^{j}\right)=\sum_{k=1}^{r} \lambda_{k} \cdot U_{k}{ }^{j}\left(\boldsymbol{x}^{j}\right), \sum_{k=1}^{r} \lambda_{k}{ }^{j}=1, \\
& \lambda_{k}{ }^{j} \geq 0
\end{aligned}
$$

と仮定する.乙こで， $x^{j}$ は地域 $j$ での属性の結果を 表わすべクトルであり, $U_{k}{ }^{j}\left(\boldsymbol{x}^{j}\right)$ は地域 $j$ の集団 $k$ の 多属性効用関数で $(2)$ 式で表わされる. $\lambda_{k}{ }^{j}$ は地域 $j$ にとっての集団 $k$ の選好の強さを示す係数である.

$\lambda_{k}{ }^{j}$ の決定方法は，対象地域に対する行政政策の目 的によってさまざまに考えうるであろう．本モデルで は，市る基準によって設定された $\lambda_{k}{ }^{j}$ を用いて得られ た，地域 $j$ の住民の満足度に関する情報が，ある明確 な意味をもって，行政の意思決定の一つの過程として 役立っていかなければならないという視点から，つぎ の三つの基準を提案する.

\section{(1) 平等基準}

この基準では， $\lambda_{k}{ }^{j}$ を地域 $j$ の集団 $k$ に属する人の 地域全体に対する人数比 $\beta_{k}{ }^{j}$ と設定する. したがっ て，個人がどの集団に属し，どのような満足度をもう ているかは考慮されず，集団の大ささのみによって $\lambda_{k}{ }^{j}$ が設定される. すなわち，個人 1 人 1 人をまった く平等と考える立場にあり, 弱者, 小数者の特別な保 護といった性格はもっていない， $U^{j}\left(\boldsymbol{x}^{j}\right)$ は集団の効 用之集団の構成比が荷重和されたあので, 地域 $j$ の住 民の平均的満足度を表現していると解釈される.

（2）目標満足度達成基準

この基準では $\lambda_{k}{ }^{j}$. は次式で定義される.

$$
\begin{aligned}
\lambda_{k}{ }^{j}= & \sum_{i=1}^{n}\left(\frac{\alpha_{i k}{ }^{j} \cdot \delta\left[\hat{u}_{i}{ }^{j}-u_{i k}{ }^{j}\left(x_{i}{ }^{j}\right)\right] \cdot \beta_{k}{ }^{j}}{\hat{u}_{i}{ }^{j}}\right) / \\
& \sum_{k=1}^{r} \sum_{i=1}^{n}\left(\frac{\alpha_{i k}{ }^{j} \cdot \delta\left[\hat{u}_{i}{ }^{j}-u_{i k}{ }^{j}\left(x_{i}{ }^{j}\right)\right] \cdot \beta_{k}{ }^{j}}{\hat{u}_{i}{ }^{j}}\right), \\
& =\left\{\begin{array}{c}
\hat{u}_{i}{ }^{j}-u_{i k}{ }^{j}\left(x_{i}{ }^{j}\right)\left(\hat{u}_{i}{ }^{j}-u_{i k}{ }^{j}\left(x_{i}{ }^{j}\right) \geq 0\right) \\
0 \quad\left(\hat{u}_{i}{ }^{j}-u_{i k}{ }^{j}\left(x_{i}{ }^{j}\right)<0\right),
\end{array}\right.
\end{aligned}
$$




$$
\sum_{k=1}^{r} \beta_{k}^{j}=1
$$

ここで, $\hat{u}_{i}{ }^{j}$ は地域 $j$ における属性 $i$ の満足度の政策 目標水準であり, $u_{i k}{ }^{j}\left(x_{i}{ }^{j}\right)$ は地域 $j$ における集団 $k$ の 属性 $i$ の 1 次元効用関数, $\alpha_{i k}{ }^{j}$ は属性 $i$ の重みである.

$\hat{u}_{i}{ }^{j}$ が閾值として作用するために， $\hat{u}_{i}{ }^{j}$ をすでに満 たしている集団の効用は無視され， $\hat{u}_{i}{ }^{j}$ に達していな い集団の効用についてのみ， $\hat{u}_{i}{ }^{j}$ までの距離とその集 団の大きさが考慮されて $\lambda_{k}{ }^{j}$ が設定され，いわば，弱 者（低満足度者）保護の立場を意味する屯のである.

(3) 目標尺度達成基準

この基準では， $\lambda_{k}{ }^{j}$ は次式で定義される.

$$
\begin{aligned}
& \lambda_{k}{ }^{j}=\sum_{i=1}^{n}\left(\frac{\alpha_{i k}{ }^{j} \cdot \delta\left[\hat{x}_{i}{ }^{j}-x_{i}{ }^{j}\right] \cdot \beta_{k}{ }^{j}}{\hat{x}_{i}{ }^{j}}\right) / \\
& \sum_{k=1}^{r} \sum_{i=1}^{n}\left(\frac{\alpha_{i k^{j}} \cdot \delta\left[\hat{x}_{i}{ }^{j}-x_{i}{ }^{j}\right] \cdot \beta_{k}{ }^{j}}{\hat{x}_{i}{ }^{j}}\right), \\
& \delta\left[\hat{x}_{i}{ }^{j}-x_{i}{ }^{j}\right] \\
& =\left\{\begin{array}{l}
\left|\hat{x}_{i}{ }^{j}-x_{i}{ }^{j}\right| \\
\left(\begin{array}{l}
\hat{x}_{i}{ }^{j} \geq x_{i}{ }^{j} \geq 0, u_{i}\left(\hat{x}_{i}{ }^{j}\right) \geq u_{i}\left(x_{i}{ }^{j}\right) \\
\text { or } \\
x_{i}{ }^{j} \geq \hat{x}_{i}{ }^{j} \geq 0, u_{i}\left(\hat{x}_{i}{ }^{j}\right) \geq u_{i}\left(x_{i}{ }^{j}\right)
\end{array}\right) \\
\left(\begin{array}{l}
x_{i}{ }^{j} \geq \hat{x}_{i}{ }^{j} \geq 0, u_{i}\left(\hat{x}_{i}{ }^{j}\right)<u_{i}\left(x_{i}{ }^{j}\right) \\
\text { or } \\
\hat{x}_{i}{ }^{j} \geq x_{i}{ }^{j} \geq 0, u_{i}\left(\hat{x}_{i}{ }^{j}\right)<u_{i}\left(x_{i}{ }^{j}\right)
\end{array}\right),
\end{array}\right. \\
& \sum_{k=1}^{r} \beta_{k}^{j}=1
\end{aligned}
$$

ここで, $\hat{x}_{i}{ }^{j}$ は地域 $j$ における属性 $i$ の結果の政策目 標水準である.乙の基準設定の立場は基準 (2)に類似 しているが，属性の結果についての集団間の効用格差 は無視され, 集団間の属性の重要度の違いのみが考慮 される. 集団間の効用格差を無視してしまう欠点はあ るものの，行政が整備しつつある社会指標などと直接 結びつきやすく，行政担当者にとって現実的に理解し やすいという実用的な利点をむつ基準ともいえる.

つぎに，地域効用関数を統合して都市全体の効用関 数を決定する問題も，地域での議論を都市全体に拡張 し，地域における集団を都市における地域と見なし て, 都市全体の効用関数 $U^{T}\left(\boldsymbol{x}^{T}\right)$ を次式で定義する.

$$
\begin{aligned}
U^{T}\left(\boldsymbol{x}^{T}\right) & =\sum_{j=1}^{p} \gamma_{j} \cdot U^{j}\left(\boldsymbol{x}^{j}\right) \\
& =\sum_{j=1}^{p} \sum_{k=1}^{r} \sum_{i=1}^{n} \gamma_{j} \cdot \lambda_{k}{ }^{j} \cdot \alpha_{i k}{ }^{j} \cdot u_{i k}{ }^{j}\left(x_{i}{ }^{j}\right)
\end{aligned}
$$

ここで， $\gamma_{j}$ は都市全体にとっての地域 $j$ の選好の強さ を示す係数である. $\gamma_{j}$ の決定方法は地域におけると同 様の考え方を適用する.

(1) 平等基準 $\gamma_{j}$ を都市全体に対する地域 $j$ の人口比 $\theta^{j}$ とする.

(2) 目標満足度達成基準

地域 $j$ の満足度の政策目標水準を $\hat{u}^{j}$ とすれば $\gamma_{j}$ は

$$
\begin{aligned}
\gamma_{j}= & \left(\frac{\delta\left[\hat{u}^{j}-u^{j}\left(\boldsymbol{x}^{j}\right)\right] \cdot \theta^{j}}{\hat{u}^{j}}\right) / \sum_{j=1}^{p}\left(\frac{\delta\left[\hat{u}^{j}-u^{j}\left(\boldsymbol{x}^{j}\right)\right] \cdot \theta^{j}}{\hat{u}^{j}}\right), \\
= & \delta\left[\begin{array}{ll}
\left.\hat{u}^{j}-u^{j}\left(\boldsymbol{x}^{j}\right)\right] \\
0 \quad u^{j}\left(\boldsymbol{x}^{j}\right)\left(\hat{u}^{j}-u^{j}\left(\boldsymbol{x}^{j}\right) \geq 0\right)
\end{array}\right. \\
& \sum_{j=1}^{p} \theta^{j}=1
\end{aligned}
$$

で定義される.

(3) 目標尺度達成基準

都市に括ける地域 $j$ の属性の結果の政策目標水準べ クトルを $\hat{x}^{j}=\left(\hat{x}_{1}{ }^{j}, \hat{x}_{2}{ }^{j}, \cdots, \hat{x}_{n}{ }^{j}\right)(j=1,2, \cdots, p)$ とすれ ば, $\gamma_{j}$ は

$$
\begin{aligned}
\gamma_{j}= & \sum_{i=1}^{n} \theta^{j} \cdot \frac{\delta\left[\hat{x}_{i}{ }^{j}-x_{i}{ }^{j}\right]}{\hat{x}_{i}{ }^{j}} \cdot \bar{\alpha}_{i}^{j} \mid \\
& \sum_{j=1}^{p} \sum_{i=1}^{n} \frac{\delta\left[\hat{x}_{i}^{j}-x_{i}^{j}\right]}{\hat{x}_{i}{ }^{j}} \cdot \theta^{j} \cdot \bar{\alpha}_{i}^{j} \\
\text { ここで, } \bar{\alpha}_{i}{ }^{j}=\sum_{k=1}^{r} \alpha_{i k}{ }^{j} \cdot \beta_{k}{ }^{j} & \text { であり, 地域 } j \text { におけ }
\end{aligned}
$$

る全住民の属性 $i$ の重みの平均值を表わし, Table 1 に一例が示される.

以上の議論から，住民の都市環境に対する評価を目 的に応じて，(6)式, あるいは (3), (2)式の形で定 量的に表現するととが可能になる．特に，行政の意思 決定過程では，(2)，（3)式が提供する地域間, 集団 間の満足度格差についての情報が重要な役割を果たす と思われる。

Table 1 Mean value and standard deviation of weight

\begin{tabular}{l|ll||l|ll}
\hline No. & Mean & S. D. & No. & Mean & S. D. \\
\hline P 1 & 0.048 & 0.029 & P 18 & 0.019 & 0.009 \\
P 2 & 0.047 & 0.022 & P 19 & 0.021 & 0.009 \\
P 3 & 0.026 & 0.014 & P 20 & 0.024 & 0.010 \\
P 4 & 0.038 & 0.018 & P 21 & 0.037 & 0.018 \\
P 5 & 0.028 & 0.014 & P 22 & 0.033 & 0.015 \\
P 6 & 0.024 & 0.012 & P 23 & 0.057 & 0.020 \\
P 7 & 0.017 & 0.010 & P 24 & 0.052 & 0.021 \\
P 8 & 0.016 & 0.008 & P 25 & 0.045 & 0.016 \\
P 9 & 0.017 & 0.010 & P 26 & 0.041 & 0.016 \\
P 10 & 0.007 & 0.005 & P 27 & 0.041 & 0.023 \\
P11 & 0.008 & 0.005 & P 28 & 0.028 & 0.013 \\
P 12 & 0.010 & 0.005 & P 29 & 0.023 & 0.011 \\
P 13 & 0.012 & 0.006 & P 30 & 0.055 & 0.026 \\
P 14 & 0.008 & 0.005 & P 31 & 0.060 & 0.027 \\
P 15 & 0.010 & 0.005 & P 32 & 0.068 & 0.029 \\
P16 & 0.008 & 0.006 & P 33 & 0.064 & 0.027 \\
P 17 & 0.009 & 0.006 & & & \\
\hline
\end{tabular}




\section{2 住民の都市環境選好構造調査}

調 査対象地域は北九州市戸畑区（昭和 53 年時点で 約人口 83000 人, 27000 世帯) で, 対象地域を $1 \mathrm{~K}^{2}$ メッシュで 8 地域に分割し, 各メッシュをクラスター と考えるクラスターサンプリングを行い，一世帯一サ ンプルとして被調査者 400 を抽出し, Fig. 1 亿示す目 標の階層構造から，各属性の重みと 1 次元効用関数を 求めるためのアンケート調查（有効解答 192）を実施 した.

各評価目標は, 調査者側で日常の生活環境に関連す る社会指標 ${ }^{7}$ の中から, 住民サイドから評価可能と思 われる項目を決定した。

属性の重みに関する質問は階層的に行い，まず，同 一階層の項目に行政課題として取り組むとしたときの 優先順位を付けてあらい，つぎに各項目の優先度合の 違いを第 1 . 順位の項目との一対比較によって, 線グラ フ上に記入してむらう形式で，乙れから比例尺度を構 成している. 最下位レベルの属性の 1 次元効用関数に 関する質問は，最も望ましい結果の満足度を $100 \%$ と し，乙の結果と調査者側で定めた特定の結果との一対 比較により，満足度(\%)を直接割り当ててもう形式を とっている.

Table 1 は属性の重みに関するデータを集計し，重 みの平均值と標準偏差を示したもので, 戸畑区住民全 体の平均的な選好構造を把握するととができる. これ

\begin{tabular}{|c|c|c|c|c|}
\hline & & & Lowest leve1 & No. \\
\hline & & Housing & {$\left[\begin{array}{l}\text { Width of room } \\
\text { Width of area }\end{array}\right.$} & $\mathrm{P} 1$ \\
\hline & environment & & -widen ot ared & P2 \\
\hline & & L Housing & {$\left[\begin{array}{l}\text { Rent } \\
\text {-Residential ownership cost }\end{array}\right.$} & $\begin{array}{l}\text { P3 } \\
\text { P4 }\end{array}$ \\
\hline & & expense & Public housing supply & P5 \\
\hline & & $\Gamma$ Socia & Water supply & P6 \\
\hline & & capital & -Sewer system & P7 \\
\hline & & stock & [Sunny time & $\begin{array}{l}\mathrm{P} 8 \\
\mathrm{P9}\end{array}$ \\
\hline & & & & $\mathrm{P} 10$ \\
\hline & Residential & -Accessi- & & $\begin{array}{l}\text { P11 } \\
\text { P12 }\end{array}$ \\
\hline & environment & bility & to a retail & P13 \\
\hline nent & & & to a kindergarten & P14 \\
\hline nment & & & $\begin{array}{l}\text { to a nospltal } \\
\text { to a park }\end{array}$ & P16 \\
\hline & & & $L_{\text {to jobs }}$ & P17 \\
\hline & & Neighbor- & Quality of a park & P18 \\
\hline & & $\begin{array}{c}\text { hood } \\
\text { service }\end{array}$ & $\begin{array}{l}\text {-Quality of a retail } \\
\text { Quality of a hospital }\end{array}$ & P19 \\
\hline & & $L_{\text {Circum- }}$ & Residential density & P21 \\
\hline & & stance & $L_{\text {Aesthetics of town }}$ & P22 \\
\hline & & Air & {$\left[\begin{array}{l}\text { Exhaust gas } \\
\text { Soot }\end{array}\right.$} & $\begin{array}{l}\text { P23 } \\
\text { P24 }\end{array}$ \\
\hline & Pollution & Water & {$\left[\begin{array}{l}\text { River } \\
\text { Sea }\end{array}\right.$} & $\begin{array}{l}\text { P25 } \\
\text { P26 }\end{array}$ \\
\hline & & & 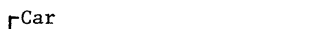 & P27 \\
\hline & & $L_{\text {Noise }}$ & Plant & P28 \\
\hline & & & Lailway & \\
\hline & & $\Gamma^{\text {Nature }}$ & {$\left[_{\text {Landslide }}^{\text {Flood }}\right.$} & $\begin{array}{l}\text { P30 } \\
\text { P31 }\end{array}$ \\
\hline & & Lire & {$\left[\begin{array}{l}\text { Initial fighting } \\
\text { Fire facilities }\end{array}\right.$} & $\begin{array}{l}\text { P32 } \\
\text { P33 }\end{array}$ \\
\hline
\end{tabular}

Fig. 1 Hierarchy of evaluating goals
から；生活利便性に関する属性よりあ生活の安全性， 健康に関する属性（災害の減少，公害の減少）を重視 している住民の考え方が観察できる.

事実，戸畑区は交通施設，下水道そのほかの生活利 便性に関する諸施設はよく整備されている一方，人口 密度の高い地域の一つで，火災の危険性が指摘されて いるとと，鉄鋼業を中心とする重化学工場群を抱え公 害環境が劣悪であるなど，戸畑区固有の問題と住民の 意識がよく詨応しているといえる.

\section{3. 住民の集団への分割}

ある個人の選好構造を加法的多属性効用関数で記述 するとき，属性の重みは属性間の相対的重要さを，1 次元効用関数は属性についての価值観を表わしている と考えられる.との章では，重みと効用関数につい て，住民をどのようにして集団に分類するかを述べ る.

\section{1 重みに関する集団の抽出}

属性の重みのつけ方によって特徴づけられる集団を 抽出するために，属性についての重みデータを多変量 とする主成分分析を適用した. 主成分は累積寄与率 60 $\%$ 以上の基準で 6 個抽出し, 因子負荷量の散布図から

Table 2 の主成分解釈を得た.

各サンプルの因子評点を 6 角形グラフで表わし， 6 角形グラフの形の類似したサンプルあるいは, 形は異 No. なっても意味的には同等な特徵と解釈されるサ ンプルを同一集団と見なして集団の抽出を試 み ${ }^{8)}$, Fig. 2 亿示す 6 集団を抽出した. Table 3 は抽出された 6 集団の特徴を示している. ここ で，集団 $(\mathrm{B}, \mathrm{C})$ および集団 $(\mathrm{D}, \mathrm{E})$ はそれぞれ 同じ傾向の特徵をあちながら，その強さが違う ことから，同一集団に集約し，集団Fはその大 きさがきわめて小さいととから本モデルでは省 略し, 最終的につぎの 3 集団を抽出した.

Table 2 Interpretation of 6 P. C. S

\begin{tabular}{|c|c|c|}
\hline & Positive & Negative \\
\hline P. C. 1 & Convenience of life & Safety of life \\
\hline P. C. 2 & $\begin{array}{l}\text { Goodness of housing } \\
\text { quality }\end{array}$ & $\begin{array}{l}\text { Decreasing of poll- } \\
\text { ution and increasing } \\
\text { accessibility }\end{array}$ \\
\hline P.C. 3 & $\begin{array}{l}\text { Decreasing of air } \\
\text { pollution }\end{array}$ & Safety of life \\
\hline P. C. 4 & $\begin{array}{l}\text { Comfortable of } \\
\text { neighborhood } \\
\text { circumstance }\end{array}$ & $\begin{array}{l}\text { No significant } \\
\text { feature }\end{array}$ \\
\hline P.C. 5 & $\begin{array}{l}\text { Goodness of neigh- } \\
\text { borhood service }\end{array}$ & $\begin{array}{l}\text { Goodness of social } \\
\text { housing service }\end{array}$ \\
\hline P.C. 6 & $\begin{array}{l}\text { Decreasing of water } \\
\text { pollution }\end{array}$ & $\begin{array}{l}\text { No significant } \\
\text { feature }\end{array}$ \\
\hline
\end{tabular}


集団 1 ：Table 1 に示す戸烟区の平均的特徽をもつ (A)

集団 2 : 集団 1 亿比較して“住宅事情のよさ’は軽視 するが“生活の安全性”を重視する ( B , C)

集団 3 ：集団 1 亿比較して‘生活の安全性’ は軽視す るものの ‘住宅事情のよさ’, ‘生活の利便さ’ を重視する（D, E)

以上の集団の抽出が適切になされたかどうかの指針 として, Table 4 に3 集団の構成員による重みの平均 值之標準偏差を重みの大きさ上位 5 位までの属性（* 印）について示した. 各集団の特徴と上位 5 位の属性 が一致していることおよび，変動係数(標準偏差/平均
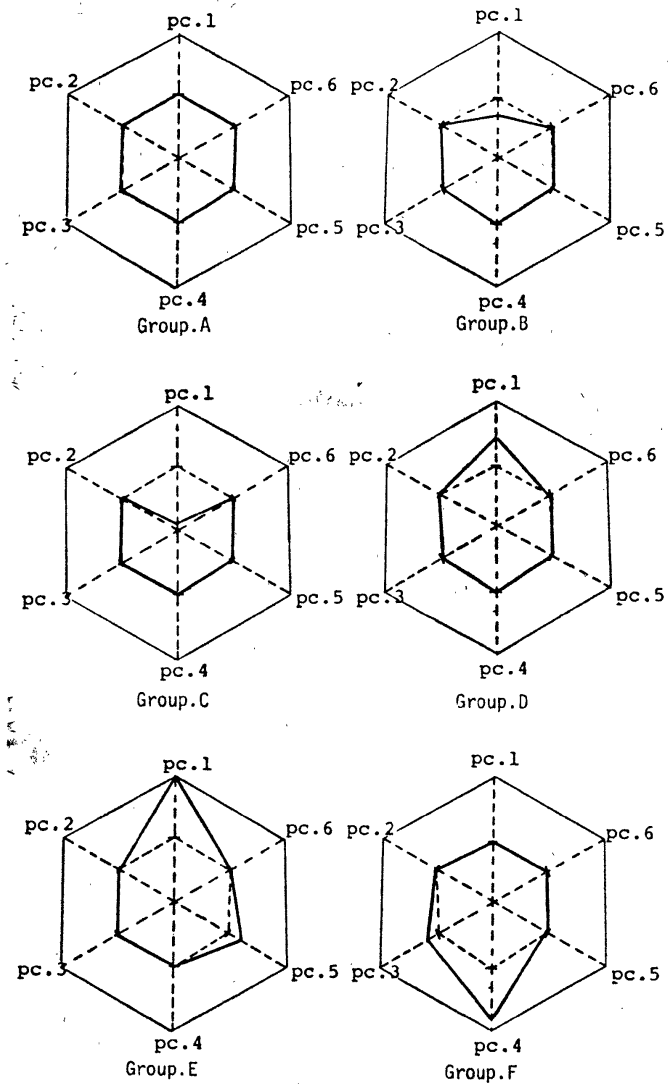

Fig. 2 Patterns of 6 groups

Table 3 Characteristics of 6 groups

\begin{tabular}{c|l}
\hline Group & \multicolumn{1}{|c}{ Characteristic } \\
\hline A & $\begin{array}{l}\text { Possessing a standard life attitude in Tobata } \\
\text { B }\end{array}$ \\
Ward \\
C & Wishing a more safety life than group A \\
D & Wishing a more safety life than group B \\
E & Wishing a more convenient life than group A \\
F & Wishing a more comfortable life than group A \\
\hline
\end{tabular}

值）が, Table 1 の場合よりあ小さくなっているとと から，適切な集団抽出がなされたと判断される．乙の 集団の重みの平均值を(2) 式の $\bar{\alpha}_{i k}$ 之定義する.

\section{2 集団の 1 次元効用関数の決定}

個人の属性の価值観は効用関数の形に反映される. たとえば，現状満足タイプの人は上に凸な効用関数を あつ場合が多く，現状不満足タイプの人は下に凸な効 用関数をあつ場合が多い，そこで，ある属性の 1 次元 効用関数を, 単調性, 凹凸性, 増加減少性などの可能 な組合せによる幾つかのパターンで表わし，サンプル がごのパターンに属すかを各集団でとに，全ての属性 について判別することにより, 集団の 1 次元効用関数 の決定を行う. 各効用関数パターンは 3 次多項式で近 似され，パラメータは最小 2 乗法によって推定する.

今, 集団 $k$ の属性 $i$ の 1 次元効用関数 $u_{i k}\left(x_{i}\right)$ が $q$ 個のパターンに分類されたとすると， $u_{i k}\left(x_{i}\right)$ は

$$
u_{i k}\left(x_{i}\right)=\sum_{l=1}^{q} \eta_{i k}{ }^{l} \cdot u_{i_{k}}^{l}\left(x_{i}\right), \sum_{l=1}^{q} \eta_{i k}^{l}=1
$$

で定義される. こてで, $u_{i k}{ }^{l}\left(x_{i}\right)$ は $u_{i k}\left(x_{i}\right)$ のパターン $l$ を意味し, $a_{i}{ }^{l} x_{i}{ }^{3}+b_{i}{ }^{l} x_{i}{ }^{2}+c_{i}{ }^{l} x_{i}{ }^{l}+d_{i}{ }^{l}$ で近似され る. $a_{i}{ }^{l}, b_{i}{ }^{l}, c_{i}{ }^{l}, d_{i^{l}}{ }^{l}$ は最小 2 乗法による推定パラメ 一タである. $\eta_{i k}{ }^{l}$ はパターン $l$ 亿属するサンプルの構 成比である. (9)式を $(2)$ 式の $\bar{u}_{i k}\left(x_{i}\right)$ と定義すれば, (2)式から集団の選好構造が決定される.

ここで，属性の尺度に主観指標を用いる場合につい て述べておく. 属性の 1 次元効用関数が住民アンケー トから求められるためには, 住民が属性の結果につい て評価可能であるととが前提であるが，“排出ガスに よる大気污染'といった属性については，NOx 濃度 （ppm）を尺度としても, 住民の効用割り当ては困難で あるうし, 効用データが得られたとしてもその信頼度 は低いと思われる. 本モデルでは，乙のような属性に 対しては，住民の効用割り当てを容易にするために主 観指標9)を積極的に用いており，Fig. 1 の P19 から

Table 4 Mean value and standard deviation of weight in three groups

\begin{tabular}{|c|c|c|c|c|c|c|}
\hline \multirow{2}{*}{ No. } & \multicolumn{2}{|c|}{ Group 1} & \multicolumn{2}{|c|}{ Group 2} & \multicolumn{2}{|c|}{ Group 3} \\
\hline & Mean & S. D. & Mean & S. D. & Mean & S. D. \\
\hline P 1 & 0.050 & 0.019 & 0.028 & 0.014 & $0.073^{*}$ & 0.035 \\
\hline P 2 & 0.047 & 0.016 & 0.033 & 0.016 & $0.067^{*}$ & 0.022 \\
\hline P 4 & 0.038 & 0.012 & 0.028 & 0.014 & $0.050^{*}$ & 0.018 \\
\hline P 23 & $0.053^{*}$ & 0.011 & $0.062 *$ & 0.020 & $0.049 *$ & 0.015 \\
\hline Р 30 & $0.059 *$ & 0.017 & $0.067 *$ & 0.031 & 0.039 & 0.018 \\
\hline P 31 & $0.061 *$ & 0.018 & $0.078^{*}$ & 0.027 & 0.040 & 0.016 \\
\hline P 32 & $0.069 *$ & 0.019 & $0.090 *$ & 0.032 & $0.045^{*}$ & 0.014 \\
\hline P 33 & $0.063 *$ & 0.017 & $0.082 *$ & 0.031 & 0.042 & 0.013 \\
\hline
\end{tabular}


P 31 および P 33 がこれに該当する.

主観指標は属性の結果の状態を Fig. 3 に示すよう な言語表現で記述し，序数尺度 1 から 5 を割り当て る.ただし，序数尺度 1 および 5 は，それぞれ最悪の 状態，最良の状態とだれもが判断可能な表現とし，効 用を $u(1)=0, u(5)=100$ と前もって設定する. アンケ ートでは, サンプルの周辺環境がどの序数尺度に該当 するかを記入（必ずしも序数尺度に一致しなくてむよ い)させ， $u(1), u(5)$ と比較して効用を割り当てさせ ている. ただし, 序数尺度 $I$ と $I+1$ の間に記入して いる場合は,リニアに基数を対応させている.

主観指標を尺度に用いた属性についての集団の 1 次 元効用関数の決定にあ (9)式と同様の考え方を適用 し, 集団 $k$ の主観指標を用いた属性 $i$ のパターン $l$ の 効用関数 $u_{i k}^{l}\left(I N_{i}\right)$ は

$$
u_{i k}^{l}\left(I N_{i}\right)=\left\{\begin{array}{l}
{\left[\bar{u}_{i}^{l}\left(\overline{I N}_{i}^{l}\right) / \overline{I N}_{i}^{l}\right] \cdot I N_{i}} \\
-\bar{u}_{i}^{l}\left(\overline{I N}_{i}^{l}\right) / \overline{I N}_{i}^{l} \quad\left(I N_{i} \leq \overline{I N}_{i}^{l}\right) \\
{\left[\left(100-\bar{u}_{i}^{l}{ }^{l}\left(\overline{I N}_{i}^{l}\right)\right) /\left(5-\overline{I N}_{i}^{l}\right)\right] \cdot I N_{i}} \\
+\left(5 \bar{u}_{i}^{l}\left(\overline{I N}_{i}^{l}\right)-100 \overline{I N}_{i}^{l}\right) /\left(5-\overline{I N}_{i}^{l}\right) \\
\left(I N_{i}>\overline{I N}_{i}^{l}\right)
\end{array}\right.
$$

なる直線近似で定義される. $I N_{i}$ は属 $i$ の序数尺度值 を表わし, $\overline{I N}_{i}^{l}, \bar{u}_{i}^{l}\left(\overline{I N}_{i}{ }^{l}\right)$ は属性 $i$ の効用関数パタ ーン $l$ に属する構成員の平均序数尺度值, 平均効用值 を表わす. Fig. 4 に上に凸で単調増加な効用関数パタ ーン 1 に， 3 サンプルが属している場合の (10)式の適 用例を示す.

\section{4. 住民の都市環境評価モデル の構成と都市評価}

この章では，3 章で述べた住民の集団化手法と集団 の選好構造の決定法を実際に適用し，2 章のモデル化 理論に従って，住民の都市環境評価モデルを構成す る. 最後に, 戸畑区の都市環境の評価の一例を示す.

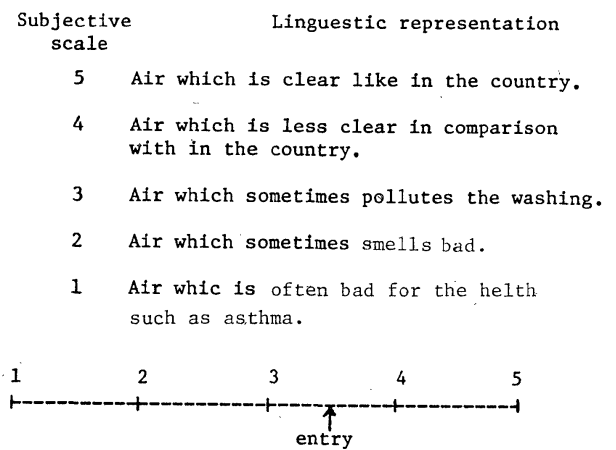

Fig. 3 Subjective scale for the attribute'Exhaust gas pollution' and an example of it's entry in the survey research

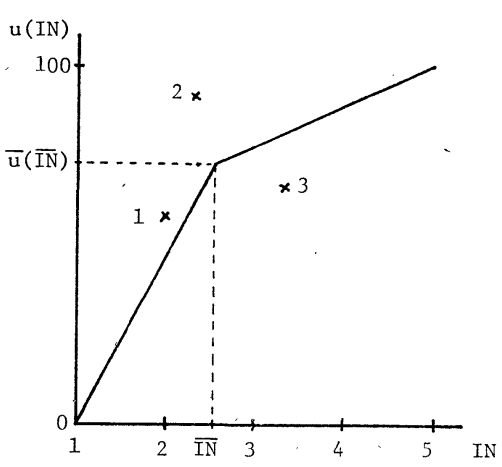

Fig. 4 An example of a lenearly approximated utility function of the attrbute using subjective scale

\section{1 住民の都市環境評価モデルの構成}

地域分割としては Fig. 5 に示す 2 地域を設定した. 地域 1 は工場地区隣接地域, 地域 2 は内陸部的地域之 いった性格をむつ. 各地域について独立に再度，住民 の集団の抽出を行うべきであるが，乙こでは簡単のた めに，3 章で抽出された 3 集団が, 両地域に同様に存 在ずるとし，地域ごとに 3 集団に属するサンプルを巽 別し，集団の重みの平均値と集団の構成比を求めた. これを後の評価例に用いる属性 P 1 と P 23 についての み Table 5 に示す.

つぎに, 全ての属性について各集団の 1 次元効用関 数を(9)，(10)式に従って地域別に決定する. Table 6 に属性 P 1 ‘部屋の広さ’について，4 種類のパターン の推定パラメータ, パターン構成比を集団 1 について のみ地域別に示す．以上から，Fig. 6 亿示す住民の都 市環境評価モデルを構成するととができる．各地域ご とに属性の尺度を計量すれば，地域住民の評価を定量 的に表わすことが可能になる.

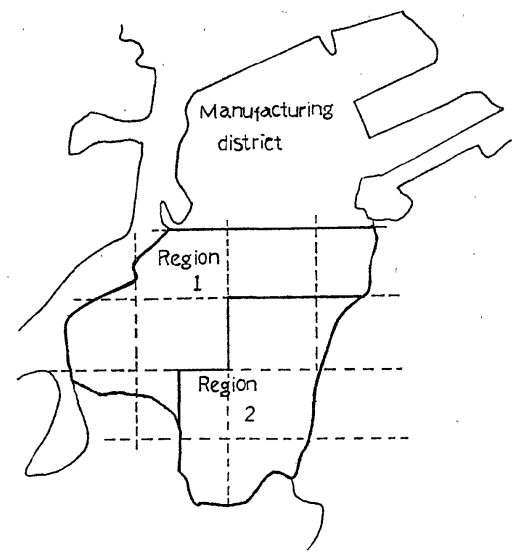

Fig. 5 An example of partition in Tobata ward 
Table 5 Mean value of weight and group ratio in each group and region

\begin{tabular}{c|ccc|ccc}
\hline \hline \multirow{2}{*}{ No. } & \multicolumn{2}{|c|}{ Region 1 } & \multicolumn{3}{c}{ Region 2 } \\
\cline { 2 - 7 } & Group1 Group2 Group3 & Group1 & Group2 Group3 \\
\hline P 1 & 0.049 & 0.025 & 0.070 & 0.049 & 0.028 & 0.085 \\
P23 & 0.052 & 0.060 & 0.046 & 0.056 & 0.064 & 0.043 \\
\hline$\beta \mathrm{j}_{\mathrm{k}}$ & 0.522 & 0.284 & 0.194 & 0.442 & 0.326 & 0.232 \\
\hline
\end{tabular}

\section{2 都市環境評価}

Fig. 6 で得られた評価モデルを用いて, 戸畑区の 都市環境評価を試みるが，現段階では属性の尺度を計 量するシステムモデルが未完成であるため, 属性 P 1 ‘部屋の広さ’, P 23 ‘排出ガスによる大気污染’につい ての現状評価を検討するに留める。（3)式における集 団効用を統合する基準として ‘平等基準” $\left(\lambda_{k}{ }^{j}=\beta_{k}{ }^{j}, \beta_{k}{ }^{j}\right.$ は Table 5 参照)を適用した場合を*で, ‘目標満足度 達成基準' $\left(\hat{u}_{1}{ }^{1}=\hat{u}_{1}{ }^{2}=\hat{u}_{23}{ }^{1}=\hat{u}_{23}{ }^{2}=60\right.$ とし, $\lambda_{1}{ }^{1}=0.354$, $\lambda_{2}{ }^{1}=0.341, \quad \lambda_{3}{ }^{1}=0.305, \quad \lambda_{1}{ }^{2}=0.415, \quad \lambda_{2}{ }^{2}=0.367, \quad \lambda_{3}{ }^{2}$ $=0.218$ ）を適用した場合を**で地域効用を表わし 評価結果を Table 7 に示している．乙れから，推察で きる住民の都市環境の評価に関する情報を考察する.

（1）地域効用を見ると，属性 P 1 に関しては地域間 で目立った差は見られず，部屋の広さはほぼ同 程度の満足度にある. 一方, 属性 P 23 亿関して は，地域間の満足度格差が顕著になる．乙れは Fig. 5 の地域分割に見られるように，地域 1 が 工場隣接地域という位置的要因による大気污染 の悪さと, 地域 2 が内陸部にあり大規模な自然 公園を内包していることによる自然環境のよさ が，住民の評価に反映したあのと思われる。し たがって， 2 属性の全効用は, 地域 2 の自然環 境のよさが反映して, 地域 2 の住民の満足度が

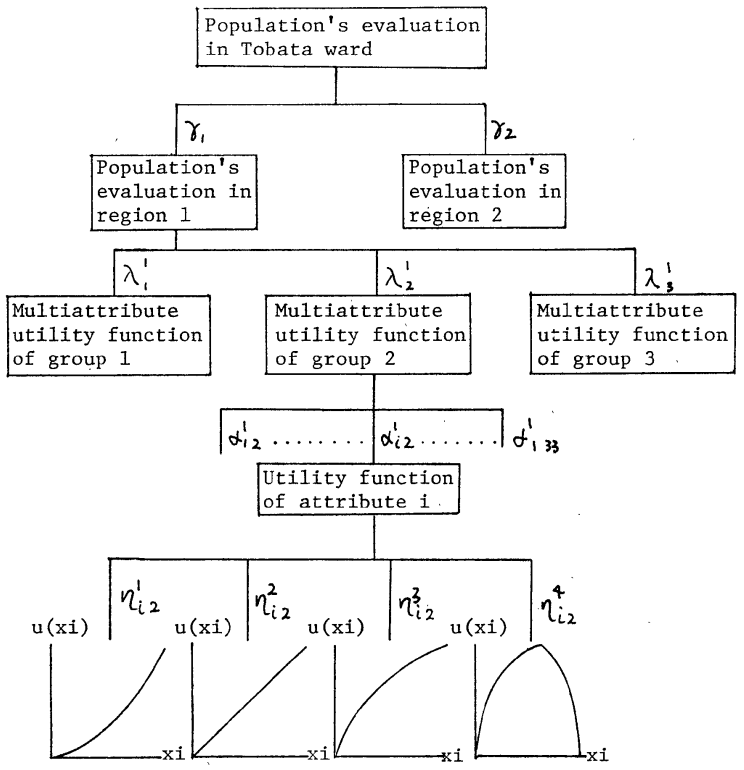

Fig. 6 Composition of population's urban environment evaluation model in Tobata ward

勝っている.

(2) 地域 1 の集団 2 は, P 1 の単独効用值は大きい あのの重み付き効用は他集団より目立って小さ く, 逆にP 23 は単独効用值は小さいむのの, 重 み付き効用は大きい，地域 2 の集団 3 について も同様な現象が見られる. このような集団に属 する人は，現在ある程度満足している属性の重 みは小さく，満足していない属性の重みは大き くするといった考え方をむつと思われる.

(3) 地域 1 のP 23 について, 各集団の単独効用值が 他より小さく， Table 5 からその重みが大きい ことから, 地域 1 の大気污染対策が成功すれば 地域 1 の住民の大きな満足度の向上が期待でき
Table 6 Parameters and ratio of utility function patterns of attribute 'Width of room' of group in each region

\begin{tabular}{|c|c|c|c|c|c|c|c|c|c|}
\hline $\begin{array}{l}u(x)= \\
b x^{2}+\end{array}$ & $\begin{array}{l}x^{3}+ \\
x+d\end{array}$ & u(x) & 1 & $\overline{(x)}$ & & $\overline{1(x)}$ & & $\overline{u(x)}$ & \\
\hline & Group & Ratio & Parameter & Ratio & Parameter & Ratio & Parameter & Ratio & Parameter \\
\hline $\begin{array}{c}\text { Region } \\
1\end{array}$ & 1 & 0.125 & $\begin{array}{ll}a & 0.0001 \\
\mathrm{~b} & 0.1009 \\
\mathrm{c}-1.5119 \\
\mathrm{~d} & 5.6926 \\
\end{array}$ & 0.500 & $\begin{array}{ll}a-0.0001 \\
b & 0.0318 \\
c & 1.8259 \\
d & -16.582 \\
\end{array}$ & 0.375 & $\begin{array}{ll}\text { a } & 0.0034 \\
\text { b- }-0.3145 \\
\text { c } & 11.564 \\
\text { d } & -74.105 \\
\end{array}$ & 0 & $\begin{array}{l}a \\
b \\
c \\
d\end{array}$ \\
\hline $\begin{array}{c}\text { Region } \\
2\end{array}$ & 1 & 0.122 & $\begin{array}{ll}a & 0.0062 \\
b-0.3490 \\
c & 7.6694 \\
d & -42.169\end{array}$ & 0.390 & \begin{tabular}{|ll}
$a$ & 0.0002 \\
$b$ & 0.0084 \\
$c$ & 2.2367 \\
$d$ & -18.557
\end{tabular} & 0.366 & $\begin{array}{ll}a & 0.0008 \\
b & -0.1350 \\
c & 8.0915 \\
d & -56.484\end{array}$ & 0.122 & $\begin{array}{l}a-0.0111 \\
b 0.5693 \\
c-3.6663 \\
d-1.3980\end{array}$ \\
\hline
\end{tabular}

る. 同じととは, 地域 2 にあいえるが，すでに単 独効用地が比較的大きな 值になっているため, 大 気污染対策そのあのが難 しくなる可能性が大き い.

(4) 目標満足度達成基準を用 いても地域 2 の満足度の 優位性は変わらないもの の, 平等基準と比較し て，効用值を低下させな がら地域間格差を縮少し 
Table 7 An example of population's evaluation for attribute P1 'Width of room' and P 23 'Exhaust gas pollution' under the present condition

\begin{tabular}{|c|c|c|c|c|c|}
\hline & \multirow[b]{2}{*}{ Group } & \multicolumn{2}{|c|}{ Region 1} & \multicolumn{2}{|c|}{ Region 2} \\
\hline & & $\mathrm{u}^{1}{ }_{\mathrm{ik}}$ & $\alpha^{1}{ }_{\mathrm{ik}} \quad \mathrm{u}^{1}{ }_{\mathrm{ik}}$ & $\mathrm{u}^{2}{ }_{\mathrm{ik}}$ & $\alpha^{2}{ }{ }_{k \mathrm{k}} \quad \mathrm{u}^{2}{ }_{\mathrm{ik}}$ \\
\hline \multirow{3}{*}{$\begin{array}{c}\text { Attribute } \\
\text { P } 1\end{array}$} & 1 & 59.70 & 2.93 & 52.09 & 2. 55 \\
\hline & 2 & 62.60 & 1.57 & 50.33 & 1. 41 \\
\hline & 3 & 55.45 & 3. 88 & 53.73 & 4. 57 \\
\hline \multicolumn{2}{|c|}{ Regional utility } & 2. $76^{* *}$ & $2.73^{*}$ & $2.57 * *$ & $2.65^{*}$ \\
\hline \multirow{3}{*}{$\begin{array}{c}\text { Attribute } \\
\text { P } 23\end{array}$} & 1 & 51.75 & 2.69 & 57.43 & 3.22 \\
\hline & 2 & 46.89 & 2.81 & 54.29 & 3.47 \\
\hline & 3 & 44.55 & 2.05 & 66.30 & 2.85 \\
\hline \multicolumn{2}{|c|}{ Regional utility } & 2. $54 * *$ & $2.60 *$ & 3. $23 * *$ & 3. $22^{*}$ \\
\hline \multicolumn{2}{|c|}{$\begin{array}{l}\text { Total regional } \\
\text { utility }\end{array}$} & $5.30 * *$ & $5.33^{*}$ & $5.80 * *$ & $5.87^{*}$ \\
\hline
\end{tabular}

て表わす傾向にある，乙れは，目標満足度達成 基準が弱者保護的意味をあつため, 満足度の高 い集団の効用が地域効用へ寄与する度合が平等 基準より抑えられ（集団の大きさにも依存）， 地域効用の大きな地域 2 のほうが抑制度合が大 きくなっているためである。

以上の 2 属性に関する現状評価の概観からです，住民 の都市環境に対する評価に関して，多くの有益な情報 を得るととができる．また，過去に，北九州市によっ て行われたアンケート結果 ${ }^{10)}$ での戸畑区のイメージと よく対応していることからす，本論文で提案した住民 の都市環境評価モデルの有效性が裏付けられる.

\section{5.おわりに}

都市行政の意思決定過程に，住民意識をいかに反映 させるかという問題に対して，住民の都市環境に対す
る価値意識の定量的な把握を実現するための，住民の 都市環境評価モデルを提案しその構筑方法を述べた。 さらに，北九州市戸畑区を対象として得られた評価モ デルと現状との対応および，現状の評価結果例からモ デルの有効性が確認された。

今後の課題として, 評価モデルと結びつくシステム モデルを開発し，評価モデルの有効性の検証をさらに 進めていく．また，北九州市全域の住民の都市環境評 価モデルを開発し，地域計画の中に適用して行きた い.

\section{参 考 文 献}

1) 松浦 : TLP システム之計画行政，西部 DSS シンポジウ 厶 (1979)

2）小澤：都市行政における住民意識の導入と評価モデルの 開発, 行動計量学, 1-2, 11/21 (1974)

3) V. Bauer and M. Wegner: Simulation, Evaluation and Conflict Analysis in Urban Planning, Proceedings of the IEEE, 163, 405/413 (1975)

4) V. Bauer and M. Wegner: A Community Ínformation Feedback System with Multiattribute Utilities, In D.E. Bell, R.L. Keeney and H. Raiffa, eds, Conflicting Objectives in Decisions, John Wiley \& Sons, Inc. (1977)

5) R. L. Keeney and H. Raiffa: Decisions with Multiple Objectives, John Wiley \& Sons, Inc. (1976)

6) 市川惊信編：多目的決定の理論と方法, 175/193, 計測 自動制御学会 (1976)

7) 国民生活審議会調查部会編：社会指標，73/96，大蔵省印 刷局 (1974)

8) 奥野: 多変量解析法, 208/218, 日科技連出版 (1971)

9) R. L. Keeney and N. Keshavan: Selecting Nuclear Power Plant Sites in the Pacific Northwest Using Decision Analysis, In D. E. Bell, R. L. Keeney and H. Raiffa, eds, Conflicting Objectives in. Decisions, John Wiley \& Sons, Inc. (1977)

10）北九州市企画局 : 北九州市新新・中期計画策定のための まちづくりに関する世論調査 (1979) 